\title{
Reframing political violence and mental health outcomes: outlining a research and action agenda for Latin America and the Caribbean region
}

\author{
Reformulando a violência política e efeitos \\ na saúde mental: esboçando uma agenda de pesquisa \\ e ação para a América Latina e região do Caribe
}

\footnotetext{
1 Douglas Hospital Research Centre, McGill University. Pavilion Perry Rm. E-2135, 6875 LaSalle Blvd, Verdun, H4H 1R3, Montreal, Quebec, Canada. duncan.pedersen@ staff.mcgill.ca
}

Abstract In recent decades, the number of people exposed to traumatic events has significantly increased as various forms of violence, including war and political upheaval, engulf civilian populations worldwide. In spite of widespread armed conflict, guerrilla warfare and political violence in the Latin American and Caribbean region, insufficient attention had been paid in assessing the medium and long-term psychological impact and additional burden of disease, death, and disability caused by violence and wars amongst civilian populations. Following a review of the literature, a few central questions are raised: What is the short, medium and long-term health impact of extreme and sustained forms of violence in a given population? How political violence is linked to poor mental health outcomes at the individual and collective levels? Are trauma-related disorders, universal outcomes of extreme and sustained violence? These questions lead us to reframe the analysis of political violence and mental health outcomes, and reexamine the notions of trauma, after which a research and action agenda for the region is outlined. In the concluding sections, some basic principles that may prove useful when designing psychosocial interventions in post-conflict situations are reviewed.

Key words Political violence, War trauma, PTSD, Mental health, Latin America and the Caribbean
Resumo Em décadas recentes, o número de pessoas expostas a eventos traumáticos tem aumentado significativamente, bem como formas de violência como guerras e revoluções políticas, que subjugam populações civis em todo o mundo. Apesar da dispersão dos conflitos armados, guerrilhas e violência política na América Latina e Caribe, atenção insuficiente tem sido dada para avaliar o impacto psicológico a médio e longo prazo e o peso das doenças, mortes, e invalidez provocadas pela violência e guerra contra populações civis. Algumas perguntas centrais são levantadas, a partir de revisão da literatura: qual o impacto na saúde da população, a curto, médio e longo prazo, ao vivenciar violências extremas e continuadas? Como a violência política se relaciona com saúde mental pobre, individual e coletiva? As desordens relacionadas aos traumas são conseqüências universais da violência extrema e continuada? Essas perguntas conduzem-nos a reformular a análise da violência politica e de suas conseqüências sobre a saúde mental, e a reexaminar as noções de trauma e a agenda da pesquisa e ação para a região. Ao final, são apresentados alguns princípios básicos que podem ser úteis ao se projetar intervenções psicossociais.

Palavras-chave Violência política, Trauma da guerra, TEPT, Saúde mental, América Latina e Caribe 


\section{Background}

There is a growing body of evidence suggesting that the interrelationships between violence and population health are more complex than initially thought.

In recent decades, the number of people exposed to traumatic events has significantly increased as various forms of violence, including war and political upheaval, engulf civilian populations worldwide; thus contributing to a lingering additional burden of disease, death, and disability 1, 2, 3, 4 .

The impact of political violence (i.e., armed conflict and guerrilla warfare, combat, imprisonment, torture, rape and other war atrocities) in the collective health and well-being of populations, at home or in exile, goes well beyond the loss of life and destruction of physical infrastructure. It is generally accepted that the devastation of the social and cultural fabric, the economic decline and impoverishment, the dislocation of people's life trajectories along with their devalued identity and value systems (which are in many ways vital for their survival), are all likely to have significant implications in the health and well-being of survivors. However, there seems to be disagreement as to specifically what and how significant is this impact in population health, and particularly in the mental health of populations.

Some of the evidence seem to suggest wars increase not only the risk of death and disability through the breakdown of the social order, but more importantly, it leads to significant increases in interpersonal violence (i.e., homicide, women and child abuse), suicide, accidents and injuries from external causes, alcohol and substance abuse, as well as higher rates of infectious diseases (i.e., malaria and tuberculosis), cervical cancer, STDs and HIV/AIDS5, 6 . These problems are compounded by the forced displacement of large segments of the population not only exposed to sustained political violence but also to various forms of assault, rape and sexual abuse and exploitation in the often harsh conditions of the sheltered zones or refugee camps. According to UNICEF, in Rwanda virtually every adolescent girl who had survived the genocide of 1994 was subsequently raped7.

From a more narrow perspective, the literature focussing on the direct health effects of political violence and wars has often attempted to establish direct linkages between the original experience of trauma and the severity and persistence of certain symptoms (i.e., anxiety, depression, alcohol and drug abuse, and Posttraumatic Stress Disorder - PTSD) in some individuals, at times for as long as 50 years.

In fact, the accumulated evidence clearly shows that in the long-term, a variable fraction of the people exposed to extreme traumatic events experience residual and persistent psychological symptoms ${ }^{8}$. In the short-term, however, there seems to be differing opinions regarding the outcomes of exposure to extreme violence. There is a long-standing controversy among experts, health professionals and therapists involved in post-conflict/disaster interventions, about the relevance and cross-cultural applicability of conventional psychiatric constructs of trauma, particularly PTSD. While some international experts have argued that the response to traumatic events involves universally recognizable patterns (including diagnosable medical conditions such as acute stress disorder and PTSD that are amenable to standard treatments), the critique from other quarters suggests that traumatic events have far broader, more varied and complex meanings and effects than those recognized by conventional psychiatric nosology or practice 9,10 . These effects, in turn, evoke a wide range of culturally specific adaptive strategies that are poorly understood.

Summerfield 11 reminds us to be more cautious in making false attributions while ignoring the presence of confounding variables in the chain of events leading to mental illness or emotional states, accompanied by vivid and painful memories of the past. In phenomenological terms, when confronting loss and extreme violence the resulting emotional reactions are not necessarily psycho-pathological, but rather illustrate aspects of regular cognitive functioning and fall within the range of "normal" psychological reactions to adversity.

While various forms of mental health intervention may have a role to play in post-conflict or post-disaster recovery (although the evidence-base for this is far from satisfactory), the medicalization of psychosocial intervention programs in terms of posttraumatic stress disorder, and related constructs, often leads to the uncritical application of symptom check-lists followed by provision of trauma counselling services. This approach reflects, in part, our limited understanding of the relationships among the range of possible health outcomes after exposure to catastrophic and traumatic events. 
Moreover, at a clinical level, we know little of who should (or should not) receive treatment, and still less about how and why treatment works in some cases, while performs poorly or is simply ineffectual in others.

In closing this section, I would like to briefly introduce the issues of resilience, social cohesion and social capital as germane to the discussion of management of trauma and postconflict recovery. There is a growing literature on resilience in the face of adversity that may have significant implications for the design and delivery of interventions. In the last three decades, a number of related constructs such as "self-efficacy"12, "hardiness"13, "resilience"14, "social capital"15, "sense of coherence"16, "recovery"17, and more recently, "post trauma growth"18, "social cohesion" and "social capital" 19,20 , feature prominently in social psychology, medical sociology and public health literature. These constructs aim at identifying endogenous, individual and collective resources and attributes having protective, restorative and healing properties, or even positive outcomes for victims and survivors exposed to adverse events and traumatic experiences. Once again, the literature seems to point at diverging ends. While some seem to emphasize the importance of resilience and social cohesion in determining health outcomes of exposure to violence, others seem to de-escalate its importance or simply ignore the influence of these factors in mental health.

\section{The regional overview: Latin America and the Caribbean}

In spite of widespread armed conflict, guerrilla warfare and political violence in the region, insufficient attention had been paid in assessing the overall psychological impact and additional burden of disease, death, and disability caused by violence and wars amongst civilian populations in Latin America and the Caribbean ${ }^{21}$.

It is beyond the scope of this paper to review the vast literature on political violence and its consequences among the people in this region. Many of the publications deal with the most direct consequences of the guerra sucia, and the traumatic experience of families of the desaparecidos and victims of torture and/or survivors of atrocities committed by military dictatorships, such as the cases of Argentina and Chile in the 1970s and 1980s22, 23, 24. Co- lombia and Haiti, two countries devastated by sustained and protracted violence, civil unrest and structural problems, have been often in the published record, but very few authors have focused on health outcomes and even less in the long-term consequences of violence. In countries like Guatemala, Nicaragua and El Salvador, there is a rising number of official reports and scientific publications dealing with the psychosocial impact of political violence and wars among local and refugee populations $25,26,27,28,29,30,31$.

In Latin America, emerging contemporary political struggles, low-intensity wars and interpersonal violence have disproportionately affected the indigenous populations. There are many recent examples of conflicts resulting in high death tolls among the Amerindian nations: the extrajudicial executions of Miskito Indians in Nicaragua; the massive killing of Mayas in Guatemala and Tzotzils in Chiapas, Mexico; the murder of Yanomami Indians in the border between Brazil and Venezuela; and the annihilation and disappearance of Quechua peasants in the Peruvian highlands. In Peru, according to the Final report submitted by the Comision de la Verdad y Reconciliación, the two-decades of armed conflict (1980-2000) between Shining Path and the military would leave in its wake an estimated total of 69,280 deaths and desaparecidos, over 600,000 people internally displaced, and an undetermined amount in material and economic losses. Most importantly, the Commission concluded that three quarters of the victims were Quechua native speakers, reflecting the deep-rooted discrimination against and marginalization of the Andean rural population impregnated in Peruvian society 32 .

In the case of Guatemala, large segments of the population were displaced because of internal conflict and violence, the majority of them Maya Indians from the Northern and Southwestern regions of the country. It is estimated that, in the last three decades, approximately 75,000 Guatemalan indigenous peoples have disappeared or been killed by violence, and more than 350,000 fled as refugees abroad, half of whom are still in Mexico and other countries of the region ${ }^{33}$. According to the Guatemalan Supreme Court of Justice, over 200,000 children have lost one or both parents because of indiscriminate violence and widespread repression.

In addition, the lives of indigenous peoples in the Andean region and Central America are increasingly under threat as they attempt to de- 
fend their land and possessions from continuous incursions by insurgent groups, special forces and the military, but also from internal power struggles generated by the arrival of migrant colonos (ranchers), mining and timber companies, drug traffickers, missionaries and religious sects, including government officials in charge of development megaprojects, often funded by international financing agencies. Today, the health of the urban-poor and rural populations of the region is clearly a reflection of the powerful interplay of their colonial past, a history of structural violence and forced acculturation, and the relentless process of global change. In the context of globalization and structural adjustment, the emergence and consolidation of neoliberal policies and free market economies, far from reducing inequalities, have widened the gap between the rich and poor, resulting in poor health outcomes. In addition, the threatening presence of multiple stressors, including violence from various sources, create new health risks and at the same time induce profound changes and transformations in collective ways of life. It is against this backdrop of poverty and powerlessness, social inequalities, and violence in its various forms, that the health status, and in particular the mental health of the local indigenous populations, must be understood.

It is within this regional context that we need to reframe the analysis of political violence and mental health outcomes, and above all reexamine the notions of war trauma and the sequelae of political violence. In the remaining sections of this paper, we outline a research agenda for the Latin American and Caribbean region, focussing our attention in the following issues: 1) the need of examining the effects of political violence and wars not only in terms of the immediate stressful events and economic and political hardships that are their inevitable precursors, but also for making the linkages between these and the broader social and economic structures in which they originate; 2 ) when trying to assess health outcomes and psychological trauma as sequelae of exposure to violence, we should approach the subject from not only the biomedical and clinical perspectives, but also from a social and epidemiological perspective. This would require the use of qualitative (i.e., ethnographic) methods in documenting local idioms of distress and the wide range of responses to trauma - including adaptive and strategic responses - at the individual and collective levels; and 3) the need to explore alternative pathways for healing and coping with the aftermath of violence and the design of innovative interventions, including the assessment of ongoing medical or psychological interventions, which may help or hinder recovery from traumatic experiences.

\section{Reexamining war trauma and trauma-related disorders}

In reviewing the literature on trauma, there seems to be consensus that it was John Erichsen, a British physician, who first referred to the notion of trauma as a mental injury in his book On railway and other injuries of the nervous system, published in $1866^{34}$. Erichsen implied that in railway accidents, invisible injuries and nervous shock were produced by shakes or concussions of the spinal cord, something he called "railway spine". The symptoms were described as being pale, feeling shaky, bursting into tears, including a state of "natural perturbation of the mind" after the railway accident, often followed by insomnia, anxiety, feeble pulse, etc. The injury of the nervous system was explained by drawing an analogy between nervous shock and the effects of a magnet struck by a heavy blow with a hammer. In the following half-century, the notions of trauma injury and nervous shock continued to evolve through the works of scientists such as Jean-Martin Charcot, Pierre Janet, W.H.R. Rivers, and Ivan Pavlov.

Toward the turn of the 20th century and the years following First World War, Sigmund Freud turned his attention to trauma as the origin of hysterical attacks and to what was later described as "traumatic war neuroses". Moving away from neurological explanations, Freud attributed the symptoms of hysteria as resulting from reminiscences or memories of the traumatic experience, also called "traumatic memory." These were the precursors to what was later described as an "epidemic of war neuroses", characterized by localized numbness, hypersensitivity and pain, anaesthesia, muscle contractions and paralyses, gastrointestinal and cardiovascular symptoms, among others, experienced among British army servicemen. This collection of polymorphic symptoms was later labelled as "shell shock" by the Royal Army Medical Corps and was attributed to the exposure to explosives in the frontlines ${ }^{35}$. In- 
terestingly, the explanation for "shell shock" was in many ways similar to the "railway spine": the exposure to shock waves produced by the proximity to an explosion caused concussions and vascular disturbances, resulting in microscopic injuries and damage to histological structures in the brain and spinal cord.

During the Second World War, large numbers of US troops exposed to combat developed a wide variety of psychiatric symptoms, often classified under the general rubric of "war neuroses". Many of these cases were described as clinical syndromes and labelled as "anxiety", "conversion states", "somatic regressions" or "psychosomatic disturbances", and treated accordingly with a wide set of therapies: abreactive therapy, drug-induced sleep, convulsive shocks, psychotherapy, and occupational therapy.

As proposed by Kirmayer ${ }^{36}$, trauma can be seen at once as a sociopolitical event, a psychophysiological process, a physical and emotional experience, usually followed by an explanation and a narrative theme. From this perspective, it can be argued that war trauma cannot only be expressed on a political level but can also be verified at multiple levels of experience: physiological changes (e.g., increased catecholamine and cortisol production), the presence of physical injuries and disabilities, stunted growth (for instance, due to malnutrition), diverse psychosocial effects, and a wide range of comorbid entities and disease conditions associated with trauma (e.g., substance abuse, tuberculosis, AIDS, etc.).

From a biomedical perspective, the neurobiology of trauma provides evidence that PTSD is biologically different from other traumatic (and non-traumatic) stress responses. A recent review of the neurobiology of $\mathrm{PTSD}^{37}$ points at three important sets of research findings: noradrenergic axis changes, neuroendocrine changes involving the hypothalamic-pituitaryadrenocortical (HPA) axis, and neuro-anatomic changes involving the hippocampus. In addition to noradrenergic changes, the exposure to extreme violence and acute stress brings out neuroendocrine changes modulated by the HPA axis: the release of corticotropin-releasing hormone stimulates adrenocorticotropic hormone, which in turn stimulates cortisol (a primary stress hormone) secretion. Cortisol activates a cascade of physiologic stress-related responses. In chronic (non-traumatic) stress HPA axis patterns seem to behave differently (as shown by lower urinary cortisol levels in veteran PTSD inpatients). In animals exposed to stressors of disrupted attachment, researchers have found damaged cells in the hippocampal region of the brain (also measured by hippocampal volume) similar to the damage induced by glucocorticoids directly implanted in the hippocampus. This preliminary evidence of changes in the hippocampal volumes (as measured by magnetic resonance imaging in combat veterans and healthy controls) suggests that changes in size and function of the hippocampus (and the amygdala) may be an important feature of chronic PTSD 38 .

Current trauma research is being undertaken not only by neuroscientists, but also by clinicians and psychologists, as well as political scientists, anthropologists, and historians. However, the majority of published studies focus on one possible main outcome of exposure to violence: Posttraumatic Stress Disorder (PTSD). The diagnostic category of PTSD was launched in 1980 by the American Psychiatric Association, in its third edition of the Diagnostic and statistical manual of mental disorders (DSM-III). The core set of disturbances and symptoms associated with PTSD are assumed to be caused by stressful experiences "outside the range of usual human experience", and connected with the Vietnam War as experienced by former combatants and patients of the US Veterans Administration. The diagnostic construct of PTSD is characterised by three main aspects: 1 ) the repeated reliving of memories of the traumatic experience (intense sensory and visual memories and intrusive recollections of the event, accompanied by extreme distress); 2) avoidance of reminders of the trauma, including emotional numbing, detachment and withdrawal, associated with an inability to experience joy and pleasure; and 3) a pattern of increased arousal (hypervigilance, irritability, sleep disturbances, and an exaggerated startle response). In chronic forms of PTSD, the pattern of hyperarousal and avoidance may be the dominant clinical features 39 .

Since the early 1980s, trauma has emerged as a key heuristic concept in much of mental health research, from developmental effects of early trauma to personality disorders to psychosis. However, some authors have begun to seriously challenge psychological or psychiatric models that posit the existence of biological, psychological, and social mechanisms, which are based on assumptions of universality of PTSD. Trauma exposure and PTSD have been 
associated with worse physical health but the relative roles of trauma exposure, with PTSD and the overall context are still contested 40 .

From a clinical perspective, the diagnostic construct of PTSD - primarily based on the experience of war veterans and victims of other types of trauma (rape, criminal assaults, torture, accidents and natural disasters ) - has advanced our understanding of the disease experience of individuals who have suffered single incident traumas (e.g., motor vehicle accident). However, these persons most often display a variety of complaints and psychological problems (e.g., somatization, depression, amnesia and dissociation, etc.), only some of which fall under the strict definition of PTSD.

Over the last few decades, the language of violence, terror and dislocation has often been conflated with the discourse of trauma and stress. In Western popular and professional traditions "trauma" has become a dominant category to explain at times the origins or cause of other problems, at times the consequences of exposure to violence brought by conflict and war. It is in the West where "trauma" has become an emblematic category that is ubiquitous and invasive in our everyday life. Its use has reached epidemic proportions: the media, the public, the sports and the arts, the scientific and the profane, all are claiming the universality of "trauma" as an unavoidable outcome of exposure to violence.

This rapidly expanding phenomenon has widely disseminated and not only popularised the notion of trauma in the general population, but also transformed its meaning and lead to what has been called the "metamorphosis of trauma". According to Young, this transformation of the notion of trauma has occurred over the last few decades (and has been reinforced and accelerated after 9/11): from being a problem limited to the war veterans and discussed by experts to a common issue discussed in daily life; from being an issue somehow restricted to those victims directly affected by events "outside the range of ordinary human experience" to a phenomenon of epidemic proportions applied to daily events, such as a traffic accident, a difficult birth, a mugging, or hearing the news that a significant other has died ${ }^{41}$.

Psychiatric teams or trauma counsellors are immediately mobilised after train and plane crashes, natural or man-made disasters, or other incidents, like a shooting or a bank robbery. In the Western nations, the growing of coun- selling services into almost every corner of life has escaped much critical enquiry, which is largely due to the difficulties of discerning when an unpleasant emotional state ends and a clinical syndrome or an abnormal state begins. The ever expanding and inclusive definition of trauma has made the objective assessment of its existence problematic, and one should exercise caution in trying to measure it.

\section{Emerging questions: outlining a regional research agenda}

From the cursory review of the literature, a few central questions relevant to the Latin American region begin to emerge: What is the short, medium and long-term health impact of extreme and sustained forms of violence in the local populations? How political violence is linked to poor mental health outcomes at the individual and collective levels? Are PTSD and other trauma-related disorders universal outcomes of violence, which can be applied as such to Latin American and Caribbean populations? What are the risk factors predicting those who will be most affected by exposure to extreme violence? What is the role of other social ills, such as racism and social exclusion, alongside poverty and wars, in determining the health and disease equation? What is the social production of collective and individual suffering? What is the role of other forces at play such as resilience, coping skills, and the density and quality of social support networks? What are the most effective interventions for promoting resilience and strengthening social cohesion in a given population affected by conflict and violence?

Whatever structural, social, and cultural factors lie upstream in the sequence of causes and health determinants, at some point - downstream - there are psychological and biological processes at work, linking the paths between the macro-contextual determinants (the political economy) with the micro-worlds of individual experience.

What are, then, the biopsychosocial pathways, if any, between ethnic conflict, political violence, wars and mental health outcomes? How does this web of causes, linkages, and pathways determine the level of suffering, disease and death in a given population? By what mechanisms do social forces ranging from poverty to racism and political violence become embodied as individual experience? 
Most of these questions have no definite answer yet. In fact, as we have seen above, scientists have been concerned about these questions since the end of the 19th century, when the meaning of "trauma" was extended from physical injury to include psychogenic ailments. But it is in the last few decades that trauma research has erupted as a major field of enquiry and taken a more ubiquitous and comprehensive character.

When trying to explain disease occurrence, distress, and social suffering in relation to violence, the contextual issues of poverty and social inequalities cannot be ignored. Critical social scientists believe that not being explicit about the context (social, political, and economic sources of inequality) contributes to an inadequate reading of the realities in which suffering and disease are produced. The neglect of the social origins of pain and suffering often results in immodest claims of causality, increases the bias toward medicalization of social problems, and ultimately leads to the widening of social inequalities.

In assessing and reacting to trauma-related conditions, it is crucially important to not only focus on the narratives of trauma and the meaning of the illness experience, but also to understand and to act on the context; that is, on the social and political determinants of health and human suffering, while staying aware of the particular stakes and interests of a given perspective and of the cultural diversity of individual and collective healing and coping responses.

As we have seen in the previous section, the medical model of trauma, however, has important limitations in capturing the complex ways in which individuals, communities, and larger groups experience massive trauma, socialize their grief, and reconstitute a meaningful existence. It has been suggested that in Latin American populations, the sequelae of trauma are experienced as a cluster of signs and symptoms transcending the narrow boundaries of PTSD and manifested in local idioms of distress and diverse somatoform disorders 42 .

From an epidemiological perspective, the magnitude and distribution of trauma-related disorders as a collective experience in local populations of the region, exposed to political violence and contemporary wars, is far from being understood. There are few and random findings, undeveloped frames for analysis and an overall lack of hypotheses on basic issues about how people experience and are affected by political violence, ethnic conflict, and wars. The preliminary results of a recent field study in the Peruvian highlands, which included a cross-sectional survey conducted among the general population of an area highly exposed to traumatic events - over a decade of extreme violence, terrorism and war atrocities -, show a large proportion of the adult population (over $50 \%$ ) scoring positive for symptoms of mental distress, and about one in four adults (over 14 years old) interviewed as symptomatic for trauma-related disorders (e.g., PTSD). Clearly, women, mainly widows and the elderly, were the most affected, not only by the long-term effects of exposure to traumatic events, but also indirectly by the disruption of their social networks, low social cohesion and relative isolation from their peers, lack of food and shelter, and other conditions generally related to the overall collapse of the local economy and extremely adverse conditions, imposed by Shining Path guerrillas and military repressive forces operating in the region 42 .

We know that most contemporary conflicts and modern warfare affect civilian populations many times more than the armed forces directly involved in the conflict (in modern warfare, death rates among the military have dropped considerably). We also know, at least in the Latin American region, that most of these armed conflicts involve politically marginal, ethnically distinct peoples, so-called "fourth-world" peoples $^{21}$. Mass terror becomes a deliberate strategy followed by both insurgent and repressive armies: the destruction of houses, schools, religious buildings, roads and bridges, animals and crops, as well as torture, rape and incarceration are commonplace. Modern warfare is concerned not only to annihilate life, but also to destroy "ways of life", trying to eliminate entire ethnic groups and eradicate entire cultures and social systems, thus undermining the critical means whereby people endure and recover from suffering and loss 10 .

Finally, we know from previous epidemiological research conducted among survivors of the Nazi holocaust that only a fraction of persons exposed to traumatic events develop longterm symptomatology compatible with PTSD 43. This was confirmed in our cross-sectional study conducted in the Peruvian highlands referred above, where only one out of every four adults interviewed $(\mathrm{N}=373)$, who were exposed to extreme violence in the decade of 1980s, reported symptoms compatible with PTSD diagnosis. 
Today, there is no humanitarian intervention or rehabilitation program that can neglect the reconstruction of the social tissue as a primary concern. Still, in every village or small scale community, there are endogenous, protective or ameliorative influences which are largely derived from resilient structures, as well as survival and conflict resolution strategies followed by communities in post-conflict. Some of these include: community-based strategies for reconciliation, ideological shifts (for instance, conversion into other religions or political conversions), spontaneous forms of enhancing social support (e.g., community festivals, religious and public ceremonies, social gathering around significant events, etc.), selfsupport groups (i.e., widows and women's community organizations), and also belief systems which provide the basis for constructing meaning for experienced trauma. Preserving and strengthening such cultural forms of support for healing and coping must be a priority in psychosocial interventions 44 .

While in the near future psychotropic drugs, counselling and psychotherapeutic techniques may become an important part of the armamentarium for targeted clinical interventions, we should not ignore the importance of indigenous resources for coping and healing, neither that a significant proportion of persons spontaneously recover from the exposure to extreme violence.

In spite of the various forms of individual therapy available (whether proven effective or not), we should acknowledge that the medicalization of rehabilitation programs, limited to the uncritical application of check-lists and provision of "trauma counselling", reflects a narrow understanding of the relationships among critically important social determinants of distress and the range of possible health outcomes after exposure to traumatic events. Moreover, we still know little of who should receive individual therapy, and even less about how and why does it work in some cases and not in others8. Furthermore, we must admit to have limited knowledge concerning how to build up, repair and reinforce social bonds and support networks, foster resilience, and increase social cohesion or social capital in societies that have been devastated by distress, massive trauma and dislocation.

Finally, most trauma intervention initiatives are expensive ventures being imported into war scenarios across the world: the West Bank,
Bosnia, Rwanda, South Africa, Central America, Peru, Nepal, Bangladesh, etc. Humanitarian interventions are - after all - an ideological product of a globalising culture and are presented as definitive knowledge and a panacea into non-Western settings. We must acknowledge that these world scenarios have differing norms, values and traditions, a range of attributions and understandings, different ways of expressing emotions, distress and suffering, and different ways of help-seeking, healing and coping with traumatic events.

\section{Implications for humanitarian assistance and psychosocial rehabilitation programs}

As a corollary of the preceding discussion, it seems timely to review some basic principles or steps to be followed, which may prove useful when designing psychosocial interventions in post-conflict situations for Latin America and the Caribbean region. These are mostly based on similar observations made by Ager 44 in waraffected populations, which were field tested and confirmed by our own experience developing a post-conflict stabilization and psychosocial rehabilitation program in the Peruvian highlands 45 .

First, all intervention initiatives in any given setting should be planned in a manner that involves minimal disruption of intact endogenous protective influences. That is, where community resilient structures and social networks have survived through conflict, assistance programs must explicitly seek to preserve those endogenous resources for coping and healing, instead of trying to replace them with outside help.

Second, where protective influences have been deactivated or are perceived clearly insufficient to ameliorate distress and experienced trauma, the intervention should aim at reestablishing protective mechanisms and provision of compensatory support from the outside, such as community development initiatives, income-generating activities (provision of small credit or financial assistance) or peace education programs.

Only when the above steps have been established and after a careful assessment of existing needs that have remained unmet, a third step can be implemented in form of a package of targeted therapeutic interventions directed to individuals, families and specific groups demanding specific attention or care. Depending 
on the resources available, screening and passive search of trauma cases could be performed by trained nurses among the clientele demanding medical services. Alternatively, case finding could be delegated to the community structures in place (i.e., community-based associations), or trained schoolteachers or key informants. The therapeutic interventions should also take into account the indigenous resources available and the community experience in what may or may not work as an effective solution. In other words, this phase should be clearly participatory; and the services to be provided derived as a negotiated product with the community at large and vulnerable groups (i.e., elderly women or widows), rather than represent the unilateral decision of a professional or an external agency.

The preferred pathway for setting up targeted therapeutic interventions would be to use a hermeneutic approach, eliciting first, the traumatic events as described by the local population, and second, the local idioms of distress and their meaning, in order to decode the patient cultural construction of his/her own illness, thus enriching and enlarging the scope of interventions and clinical management of individual cases.

In designing humanitarian responses and strategies for healing and coping with violence and adversity, we need to replace the current narrow focus on the intrapsychic and psychological mechanisms, with a wider approach aimed at the social context and community life in which people recover from traumatic experiences. As proposed by Bracken \& Petty, rethinking the trauma of extreme violence and war means shifting away from targeting individuals or groups, such as rape or torture victims. It involves a concern to help rebuilt, or invent anew, the social structures through which lives are lived and found to have a meaning. Normalization and recovery, from this perspective, touches all aspects of social and economic survival, involving the context in which development and learning takes place and, for all people, it involves the notions of social justice, solidarity, reconciliation and the break of the cycles of violence and impunity 10 .

Ongoing experiences in post-conflict stabilization and psychosocial rehabilitation in the Latin American region suggest that the goals for peace, reconciliation and economic recovery cannot be secured by unilateral ad hoc interventions aimed exclusively at trauma victims and their families. The underlying problems require the participation across the range of sectors (agriculture, finance, credit, health, education and justice), which may in turn involve establishing an open dialogue with the international agencies, donors and financial institutions as well as with national, regional, and local authorities.

Finally, these approaches to humanitarian responses in the Latin American region will require - both in the short and the long run first, a more robust database and empirical evidence derived from research; second, a far greater input from the social sciences in both research and action programs; and third, a sense of social justice and above all "accountability" on part of the international community of donors, government agents and scientists, beyond of what currently exists.

\section{References}

1. Pedersen D. Political violence, ethnic conflict, and contemporary wars: broad implications for health and social well-being. Soc Sci Med 2002; 55(2):175-90.

2. Ghobarah HA, Huth P, Russett B. The post-war public health effects of civil conflict. Soc Sci Med 2003; 59(4):869-84

3. Gustafson P, Gomes VF, Vieira CS, Jensen H, Seng R, Norberg R, et al. Tuberculosis mortality during a civil war in Guinea-Bissau. JAMA 2001; 286(5):599-603.

4. Roberts L, Hale C, Belyakdoumi F, Cobey L, Ondeko $\mathrm{R}$, Despines M, et al. Mortality in Eastern Democratic Republic of Congo. New York: International Rescue Committee; 2001.

5. Parker R. The Global HIV/AIDS pandemic, structural inequalities, and the politics of international health. Am J Publ Health 2002; 92(3):343-46.

6. Elbe S. Strategic Implications of HIV/AIDS. The Adelphi Papers 2003; 357(1).

7. United Nations Children's Fund. The state of the world's children. Oxford: Oxford University Press; 1996.

8. Yehuda R, Hyman SE. The impact of terrorism on brain, and behavior: what we know and what we need to know. Neuropsychopharmacology 2005; 30:1773-80.

9. Young A. The harmony of illusions: inventing posttraumatic stress disorder. Princeton, NJ: Princeton University Press; 1995.

10. Bracken PJ, Petty C, editors. Rethinking the trauma of war. London: Free Association Books, Save the Children; 1998.

11. Summerfield D. War and mental health: a brief overview. BMJ 2000; 321:232-35. 
12. Bandura A. Self-efficacy: toward a unifying theory of behavioral change. Psychol Rev 1977; 84:191-215.

13. Kobasa SC. Stressful life events, personality, and health: an enquiry into hardiness. J Pers Soc Psychol 1979; 37(1):1-11.

14. Rutter M, Caspi A, Moffitt TE. Using sex differences in psychopathology to study causal mechanisms: unifying issues and research strategies. J Child Psychol Psychiatry 2003; 44(8):1092-1115.

15. Bourdieu P. The forms of capital. In: Richardson JG, editor. Handbook of theory and research for the sociology of education. New York: Greenwood; 1986. p. 241-58.

16. Antonovsky A. Unraveling the mystery of health: how people manage stress and stay well. San Francisco: Jossey-Bass; 1987.

17. Harvey MR. An ecological view of psychological trauma and recovery. J Trauma Stress 1996; 9(1):3-23.

18. Tedeschi RG. Violence transformed: posttraumatic growth in survivors and their societies. Aggression and Violent Behaviour 1999; 4(3):319-41.

19. Coleman JS. Foundations of social theory. Cambridge, MA: Harvard University Press; 1990.

20. Putnam RD. Bowling alone: the collapse and revival of American community. New York: Simon and Schuster; 2000.

21. Pedersen D. El impacto de la pobreza, el racismo y la violencia política sobre la salud mental de los pueblos indo-americanos. In: Bronfman M, Castro R, organizadores. Salud, cambio social y política: perspectivas desde América Latina. México: Edamex; 1999. p. 163-84.

22. Suárez-Orozco M. A grammar of terror: psychocultural responses to state terrorism in dirty war and post-dirty war Argentina. In: Nordstrom C, editor. The paths to domination, resistance, \& terror. Berkeley: University of California Press; 1992. p. 219-59.

23. Lira E. Psicología de la amenaza política y del miedo. Santiago de Chile: Editorial Chileamérica; 1991.

24. Amnesty International. Annual review 2001. London: A.I. Publications; 2001.

25. Americas Watch, Physicians for Human Rights. Guatemala: getting away with murder. New York: Americas Watch; Somerville, MA: Physicians for Human Rights; 1991.

26. Dickson-Gomez J. Growing up in guerrilla groups: the long-term impact of being a child soldier in El Salvador's civil war. Ethos 2002; 30(4):325-56.

27. Garfield RM. War-related changes in health and health services in Nicaragua. Soc Sci Med 1989; 28(7):669-76.

28. Lundgreen RI, Lang R. "There is no sea, only fish": effects of United States policy on the health of the displaced in El Salvador. Soc Sci Med 1989; 27(7): 697-706.

29. Martin-Baro I. Political violence and war as causes of psychosocial trauma in El Salvador. Int J Ment Health 1989; 18(1):3-20.

30. Martin-Baro I, Aron A, Corne S. Latin American psychology and social commitment. Contemporary Psychology 1996; 41(5):468-69.

31. Summerfield D, Toser L. Low intensity war and mental trauma in Nicaragua: a study in a rural community. Med War 1991; 7(2):84-99.

32. Comisión de la Verdad y Reconciliación. Informe final. Lima: CVR; 2003.

33. Oficina de Derechos Humanos del Arzobispado de Guatemala. Guatemala: nunca más. Informe del Proy- ecto Interdiocesano de Recuperación de la Memoria Histórica. Guatemala: REMHI; 1998.

34. Erichsen JE. On railway and other injuries of the nervous system. London: Walton \& Maberly; 1866. [Cited in Young A, editor. The harmony of illusions: inventing post-traumatic stress disorder. Princeton, NJ: Princeton University Press; 1995. p. 13-19.]

35. Young A. Making traumatic memory. In: Young A, editor. The harmony of illusions: inventing posttraumatic stress disorder. Princeton, NJ: Princeton University Press; 1995. p. 13-42.

36. Kirmayer LJ. Confusion of the senses: implications of ethnocultural variations in somatoform and dissociative disorders for PTSD. In: Marsella AJ, Friedman MJ, Gerrity ET, Scurfield RM, editors. Ethnocultural aspects of Posttraumatic Stress Disorder: issues, research and clinical applications. Washington, DC: American Psychological Association; 1996. p. 131-63.

37. Vedantham K, Brunet A, Neylan TC, Weiss DS, Marmar CR. Neurobiological findings in Posttraumatic Stress Disorder: a review. Dialogues Clin Neurosci 2000; 2(1):23-9.

38. Nemeroff CB, Bremner JD, Foa EB, Mayberg HS, North CS, Stein MB. Posttraumatic stress disorder: a state-of-the-science review. J Psychiatr Res 2006; 40(1):1-21.

39. van der Kolk B. Posttraumatic stress disorder and the nature of trauma. Dialogues Clin Neurosci 2000; 2(1):7-22.

40. Gorst-Unsworth C, Goldenberg E. Psychological sequelae of torture and organised violence suffered by refugees from Iraq. Trauma-related factors compared with social factors in exile. Br J Psychiatry 1998; 172:90-4.

41. Young A. A description of how ideology shapes knowledge of a mental disorder (Posttraumatic Stress Disorder). In: Lindenbaum S, Lock M, editors. Knowledge, power, and practice. Berkeley: University of California Press; 1998. p. 108-28.

42. Pedersen D, Gamarra J, Planas ME, Errázuriz C. Violencia política y salud mental en las comunidades altoandinas de Ayacucho, Perú. In: Cáceres C, Cueto M, Ramos M, Vallenas V, organizadores. La salud como derecho ciudadano: perspectivas y propuestas desde América Latina. Lima: Universidad Peruana Cayetano Heredia; 2003. p. 289-307.

43. Breslau N. Epidemiology of trauma and posttraumatic stress disorder. In: Yehuda R, editor. Psychological trauma. Washington, DC: American Psychiatric Press; 1998. p. 1-30.

44. Ager A. Tensions in the psychosocial discourse: implications for the planning of interventions with waraffected populations. Dev Pract 1997; 7(4):402-7.

45. Pedersen D. Pathways for healing and coping with violence, terror and dislocation. In: Rehabilitation and Research Centre for Torture Victims, Oficina de Derechos Humanos del Arzobispado de Guatemala, editors. Guatemala: mental health and community intervention (Special report). Ciudad de Guatemala: ODHAG; 2002. p. 93-102.

Article presented in 9/03/06

Approved in 23/03/2006

Final version presented in 23/03/2006 